\title{
A recreational carrying capacity assessment of the 16th century Spanish Fort of Santiago on the Island of Chikly, Tunisia
}

\author{
M. J. Viñals ${ }^{1}$, I. Martínez ${ }^{1}$, A. Abdennadher ${ }^{2} \&$ L. Teruel $^{1}$ \\ ${ }^{1}$ Universitat Politècnica de València, Spain \\ ${ }^{2}$ Université de Carthage, Tunisia
}

\begin{abstract}
The increase in cultural tourism has revealed the vulnerability of the heritage resources during the phase of tourism exploitation and, thus, the need to set limits and to establish visitor management tools to ensure the conservation of the heritage resources and the visitors' satisfaction.

This work focuses on the determination of the recreational carrying capacity of the Fort of Santiago monument located on the Island of Chikly (Tunisia), situated in the Northern Lagoon of Tunis, which is declared a Nature Reserve for its ornithological interest. Furthermore, it has always attracted people from many civilisations, as evidenced by the Phoenician, Punic, Roman, Byzantine, Arab, Spanish and Turkish remains discovered there.

The Fort of Santiago is one of the most important monuments of 16th century. Emperor Charles I of Spain ordered the construction of the fort in 1535. A few years later, the fort passed into Turkish hands. Subsequent to transformation processes and changes of use, it was abandoned in the 19th century. In the 21st century, the monument was restored for tourism purposes.

The results of this assessment specifically highlight the greater fragility of the island in relation to the Fort of Santiago, and the need to control the visitor use level. Thus, one group of 20 people per day would be an acceptable volume of visitors. Tourism management guidelines and environmental, cultural and social performance standards and monitoring indicators are also identified to guarantee the conservation and wise use of this valuable heritage site.

Keywords: defensive architecture, recreational carrying capacity, heritage management, conservation standards and indicators.
\end{abstract}




\section{Introduction and objectives}

Heritage protection and conservation in areas of unique scientific, natural, cultural, artistic and/or historical value have been traditionally important issues in the framework of heritage planning and management.

Among the different tools considered in tourist planning and management, the Recreational Carrying Capacity (RCC) is one of the most recognised tools to guarantee the protection of the site and the quality of the visitor experience. It sets the limits of the established and desired site conditions according to the proposed visitor use level and conservation goals. The first study focused on the relationship between visitor use and environmental conditions, with the working hypothesis that increasing the number of visitors causes greater environmental impact [1-10]. Furthermore, other authors have incorporated a carrying capacity analysis of the social dimensions that address aspects of the visitor experience [11]. This approach has been followed, for example, by Shelby and Heberlein [12], Tarrant and English [13], Lindberg and McCool [14], Viñals et al. [15].

All this time, small islands have received special attention because of their intrinsic fragility; however, little research about the RCC of historical buildings has been conducted. The few examples of such research include the cases of the highly visited sites of Alhambra de Granada in Spain [16], the Archaeological Park of Petra in Jordan [17, 18], the Palace of Versailles [19] in France, or Alcatraz Island in the U.S. [20].

This paper describes a programme of research to estimate and manage the RCC of the Island of Chikly and the Fort of Santiago (Tunisia), by addressing resources and social components. The study includes the identification of standards and the related indicators of natural and cultural resource conservation and quality of the visitor experience as well as the numerical estimation of maximum daily use levels without violating quality standards.

\section{Methodology}

The RCC assessment seems to be a simplistic and easy-to-implement tool, but it is quite a complex issue. From the beginning, academic studies have exposed its limitations and, as Cole and Carlson [21] stated, the carrying capacity is more a type of logical thinking than a metric issue.

This research includes tasks such as identifying management objectives, studying specific site conditions and determining the resource desired conditions (standards and indicators), analysing factors influencing impacts, identifying limiting factors, studying the entire suite of visitor management activities and further actions to be taken (recommendations). Nevertheless, it has been necessary to develop numerical visitor estimates.

This research includes standards of quality that represent the point at which damage occurs, either unacceptably impacting the ecological or cultural conditions or the visitor experience. It is a concept closely linked to the Limit of Acceptable Change (LAC) approach in which the amount of change to be allowed is defined explicitly by quantitative standards [22-24]. The development of standards and 
indicators for a historical building is an innovative approach unique to this study, as not too many studies expand upon these concepts.

It should be noted that traditionally, RCC studies have mainly worked with a perspective orientated to the biophysical components and impacts; however, in this case, it is clear that historical buildings and heritage sites can also be included in this concept. Among the different standards identified for each resource or site, following Cole and Carlson [21], only one has been considered a limiting factor in any analysis area, and usually it will be the most sensitive threshold that is compromised at the lowest use level.

The operational procedure for the analysis of RCC starts with the study of its key components:

a) The area or spatial analysis has been developed by using a 'zoning' tool that helps when different types of spaces exist. The analysis of any space has been defined by its size and biophysical and cultural features and also by the type and timing of activities taking place. Sources of information for this task include direct observation, ornithological and database reports, resource conditions, bibliographical references, information on the internet, applicable landscape-level assessments, monitoring data, and reviews of legal policy and planning documents.

Different spaces where recreational activities will take place have been studied: the Nature Reserve of Island of Chikly, the Spanish Fort of Santiago, and complementarily, the Northern Lagoon of Tunis.

Currently, no visiting activities are permitted at the Island and the Fort. In fact, this RCC assessment is considered to be a preventive tool to be applied before opening the site to the public.

b) The cultural, natural and scenic resources of the sites have been analysed following both a descriptive and evaluative process by developing an inventory and an intrinsic and recreational assessment of the existing resources. The significance, representativeness, and singularity have been criteria considered in the intrinsic value analysis. Recreational criteria that have been taken into account for the evaluation of the tourism potentials include attractiveness, accessibility, fragility/vulnerability, feasibility, availability, educational values and increasing awareness values.

The most significant resources of the site are avifauna and the historical building of Fort of Santiago.

c) Regarding visitors, it is important to highlight that the pursued goals in implementing the RCC are to avoid recreational impacts on the site and to enhance visitor satisfaction by offering a quality experience. A demographic visitor study is not enough to achieve this second goal; rather, a visitor behaviour analysis is needed to understand the different types of visitors and their motivations. In the framework of this study, the visitor analysis was made through the study of comparable cases in other similar Spanish sites (the Nature Reserve of the Columbretes Islands, the Natural Park of the Albufera de Valencia and the Iberian archaeological settlement of the Castellet de Bernabé). In addition, several workshops and interviews with stakeholders and 
direct observation campaigns were performed in order to approximate this type of information.

The analysis of social standards and indicators are components of the "Visitor Impact Management' [25] and the 'Visitor Experience and Resource protection' [26].

\section{Spatial analysis and site conditions}

The Island of Chikly is located in the Northern Lagoon of Tunis and covers an area of 3.5 ha. The wetland was declared as a Ramsar site (International Ramsar Convention on Wetlands) in 2013, and the island has been classified as a Nature Reserve since 1993 and an Important Bird Area (Birdlife IBA Programme) because of the importance of its aquatic birds, particularly its large colony of little egrets (Egretta garzetta) that disappeared for a few years and came back to the island in 2007. Now, the little egrets are sympatrically breeding on the ground, the Fort and the trees, together with the yellow-legged gull (Larus michahellis) [27, 28].

Moreover, this small island holds Phoenician, Punic, Roman, Byzantine, Arab, Spanish and Turkish archaeological remains that evidence the historically close relation of Tunis with its lagoon. Nevertheless, the most significant cultural heritage of the island is the defensive Spanish Fort of Santiago (fig. 1).

There are many examples around the world of very small islands hosting historical buildings, especially fortresses, castles and prisons such as the medieval forts in Maharashtra (India) reported by Narkhede and Morris [29]; the 12th century Crusader's Citadel on the Pharaoh's Island (Egypt); the 17th century San Pedro of Alcántara Castle situated on the Mancera Island (Chile); the French 17th century Fort Louvois located on the Charentes archipelago; the naval Fortress of Alexander constructed on an artificial island in the 19th century near Kronstadt (Russia), since converted into a research laboratory; or the World Heritage site of Suomenlinna Fortress in Helsinki (Finland) dated from the 18th century. Most of them are currently adapted to modern tourist uses such as visitor centres and museums.

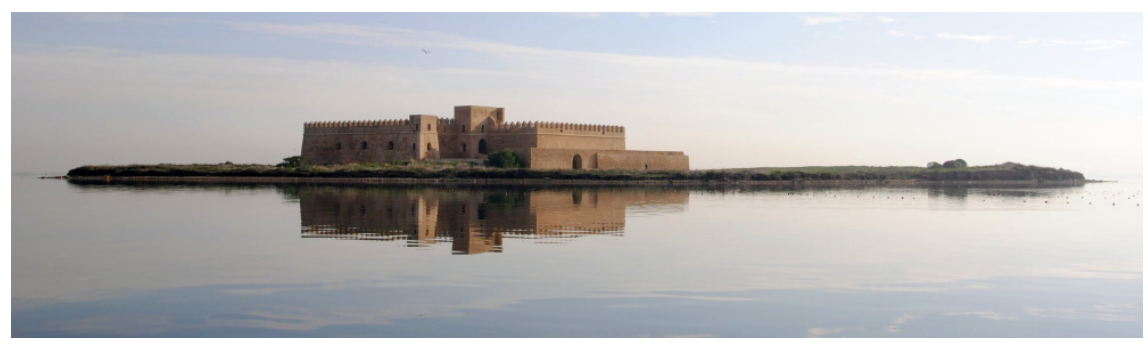

Figure 1: Island of Chikly and Spanish Fort of Santiago (Tunisia).

The Fort of Santiago, declared a historical monument in 1992, is a defensive fortification of the 16th century built by the Emperor Charles I of Spain as a defensive bastion when Spain took the coasts of Tunis. In 1574, it fell into Turkish 
hands and was used for military purposes during different governances. The Spanish writer Miguel de Cervantes, who took part in the expedition of Don Juan the Austria, narrated the fall of Tunis in his book "Don Quixote", making reference to Chikly. Afterwards, in the 18th century, the garrison was removed and became a quarantine hospital, and in the 19th century the Fort was definitively abandoned. At the end of the 20th century, the Tunisian Republic and the Government of Spain signed a Protocol for the restoration of the Fort.

At present, the Fort of Santiago covers an area of $2.400 \mathrm{~m}^{2}$ and is currently organised into different levels, with a rectangular main building that shelters two towers of different heights and an attached body that houses the cistern. The main floor is organised around a courtyard, composed of 19 rooms to host the garrison. Between these rooms is a Muslim prayer hall as a columned room under vaults [30]. There are three stairs, two in the body of the tower and one in the western corner attached to the crenelated terrace. From this terrace, another ladder goes to the balcony of the tower.

\section{Standards and indicators}

As the most sensitive items, the most fragile/vulnerable resources on the Island of Chikly and the Fort of Santiago are considered first in the selection of the conservation standards and related indicators.

For the Nature Reserve of Chikly, conservation standards focused on avifauna because birds are the most vulnerable resource on the island. Therefore, the stable population of Egretta garzetta has been the conservation standard because it is closely related to the management objectives of wilderness conservation. To monitor this standard, the number of nests has been identified as an indicator. This standard has been selected as the ecological limiting factor.

Regarding the Fort of Santiago, it should be said that it is a more robust resource than the Island and for this reason can host a higher visitor use level. Architectural conservation standards have been established considering the integrity of the structure of monument. This refers to the state of the original preservation and attributes of the Fort. This standard aims to identify structural or material changes that indicate consolidation problems. The conservation conditions of reference are those of the last restoration completed in 2009. The indicator for this standard of integrity requires an assessment of potential changes in all elements registered in the Fort (e.g., fractures and deformations). At this point, it should be noted that to date, some damage has already been observed (e.g., block collapses, falls, fissures and cracks, loose tiles, destruction of the factory walls and the destruction of pavement) that need to be restored. Architectural integrity has been consequently chosen as a building heritage limiting factor.

Spatial availability is the one social standard in relation to the quality of visitor experience. It incorporates some elements of the 'visitor psychological comfort' and the identified indicator for monitoring this standard has been the PAOT ('people-at-one-time'). Another indicator is the number of groups encountered along the Island trail or in the Fort. Field observations show that most visitors like visiting these unique places in the context of a quiet atmosphere with an acceptable 
solitude level. Stankey and McCool [31] add that the importance of the experience greatly influences attitudes toward encounters with others and measures of satisfaction. Manning et al. [32] staged such as a potential indicator of quality for the visitor experience at the Boston Harbor islands National Recreation Area by evaluating the amount of litter, vandalism and graffiti. These recreation-related impacts on the resources can also be applied to the Island and the Fort of Santiago. The social limiting factor is definitively related to PAOT considerations.

\section{Results and discussion}

The process of setting up the aforementioned carrying capacity components was drawn following the classical three consecutive level approaches proposed by Cifuentes [33] and Ceballos-Lascurain [34]: physical carrying capacity (PCC), real carrying capacity (ReCC), and effective carrying capacity (ECC).

The PCC is a numerical approach to determine the maximum number of visitors that an area is actually able to support. It essentially addresses spatial considerations and is easier to define in limited well-defined areas. Spatial zoning and mapping are the main tools used to conduct this phase of the study. It can be easily calculated by following Boullon's formula [35]: area used by visitors divided by the individual spatial standard. Then, the peak capacity is obtained, and the daily visitor use level is assessed by applying a rotation coefficient (number of daily hours available for the visit divided by average time of the visit). Weekly, monthly and yearly $\mathrm{ReCC}$ calculations require more accurate studies because visitor impacts are cumulative.

The individual spatial standard is directly linked with the 'visitor psychological comfort'. Proxemic studies developed by Hall [36] state that inter-personal space in a social context is $120 \mathrm{~cm}$. When developing dynamic activities, the World Tourism Organization [37] identifies approximately $4.00 \mathrm{~m}^{2}$ as the spatial standard in recreational outdoor activities.

After a first analysis on the Island and the Fort to determine the different physiographic and/or structural units, the identification of risk areas for visitors and accesses was performed. The results suggest that the only available space on the Island for visits was a circular trail of $850 \mathrm{~m}$ in length and $2.5 \mathrm{~m}$ wide. If the needed space for each visitor taking part in a group activity in outdoor spaces without physical barriers is $4.00 \mathrm{~m}^{2}$, and if we apply a trail occupancy rate of $10 \%$, a simple calculation brings up a maximum of 53 people visiting the site at one time.

The rooms on the ground floor of the Fort cannot be transited due to access difficulties. The most passable areas are on the main floor. The courtyard, with an area of $607.2 \mathrm{~m}^{2}$, is completely usable. There are six suitable rooms for recreational activities, each with an area of approximately $8.00 \mathrm{~m}^{2}$. If the interpersonal spatial standard per user of $1.2 \mathrm{~m}^{2}$ is applied, each room is able to accommodate 6 visitors. The upper floor has a significant decrease of surface due to the lack of security measures such as handrails. The terrace has $292.1 \mathrm{~m}^{2}$ of free movement area, and the tower has $17.4 \mathrm{~m}^{2}$; applying the spatial standard of $1.2 \mathrm{~m}^{2}$, these areas could accommodate 14 visitors (fig. 2). 


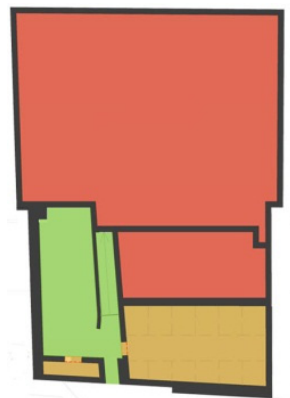

Ground Floor

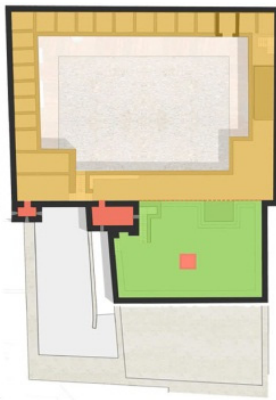

Main Floor

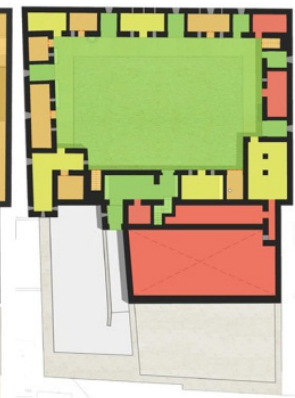

Upper Floor

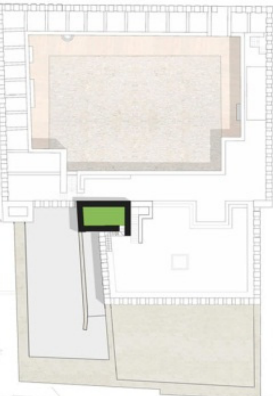

Terrace Floor

Visible Area - Not Accessible

Inaccessible Area

Accessible Area not Included in the Interpretative Visit

Accessible Area not Included in the Interpretative Visit

Figure 2: $\quad$ Plans of the different floors of the Fort of Santiago.

The second stage of the process is to evaluate the real carrying capacity. This stage of the process deals basically with the study of the limiting factors, reducing the amount of visitors obtained from the previous PCC calculation. It intends to identify the best places for hosting the planned activities where impacts are lowest. This study includes the analysis of the physical, ecological and social constraints.

After studying the physical conditions and available space (space limiting factors) of the Island and the Fort, the area has been assessed for the existence of restricted point zones due to ecologic and historical resource values. Ecological limiting factor, as stated before, is nesting birds, as they are the most significant protected resource.

Regarding the Fort of Santiago, it must be stated that the architectural limiting factor of integrity leads this stage of the study. The Fort is affected by natural damage caused by weathering, but impacts due to visitors such as mechanical degradations (falling of blocks and fabric degradation), which are closely related to the action of stepping on the settlement structures, have been detected. Using this information, another zoning map was established to take into consideration the most inherently resistant areas. Then, after establishing the fragile zones, the visitor touring pattern was positioned in the areas more appropriate for visitor use. These results also provide information about the elements that need particular protection and the need to apply some reductions in the number of visitors or activities according to the impact of the visitor use level.

Limiting social factors are related, as mentioned, to visitor psychological comfort and with the needs, wants and expectations of people, in the determination of appropriate space use. User perceptions and opinions of what types of use and use levels are appropriate are an essential element of the carrying capacity prescriptions. In this stage of the study, the social standards such as the scenery where the activity is developed (indoor, outdoor with/without physical barriers, topography, floor conditions, and length of the itinerary,) must be taken into account; the thermo-hygrometric features conditioning the human climatic 
comfort levels (weather limiting factors); the visitor motivations and behaviours; visitor expectations, the existing facilities (facilities limiting factor); and the safety conditions (safety limiting factor).

All these limiting factors have been considered in the concept of "visitor psychological comfort' and have been analysed in combination with the standard of 'groups encountered' and an 'acceptable solitude level'. Additionally, the spatial availability and the landscape type have played an important role in determining the social limiting factors because it is a flat and very small island with a very high visual fragility that makes it difficult to maintain its integrity. Visitors should be considered intrusive elements in the natural landscape; then, the maximum number of groups encountered per day must always be 0 , although the group size must also be small (10) because the available space for visitor use is scarce and resource impacts to the wildlife (birds) can be high.

Equipment and safety conditions represent an additional major limiting factor because there is no basic infrastructure such as power, a water supply or a restroom.

The 53 users obtained from the previous calculation should be reduced to increase the margin of prevention when transiting areas near nests, awarding each user a spatial standard of $10 \mathrm{~m}^{2}$. This reduces the capacity to 21 visitors.

The physical conditions of the Fort have been one of the limiting factors taken into account for this analysis. However, the Fort presents a larger capacity to accommodate more visitors than the Island. A margin of $0.70 \mathrm{~m}$ must be added to the walls where panels are located in order to have a proper focal distance for reading. When applied to the rooms assessed to accommodate 6 users in the preceding stage, the effective area of each room is reduced to $2 \mathrm{~m}^{2}$, which translates into an occupancy of 2 persons in a room at the same time. With 6 available rooms, a maximum of 12 visitors is really a very low number for this monument. The limiting factors in the case of the tower are related to the intrusion of the visitors themselves in the visual area of the panoramic view of observers. Therefore, the perimeter of the tower $(13.5 \mathrm{~m})$ determines the number of people who can simultaneously enjoy the views from the tower (13).

Finally, the third analytical level is the effective carrying capacity that addresses the managing capacity of the corresponding site administration (managerial limiting factor). Managing capacity is defined as the sum of conditions that the site administration requires in order to carry out its functions and objectives [38], and it is a crucial concern in implementing the ReCC.

Measuring managing capacity is not an easy task because many variables (several of which are quite subjective) are involved, such as policy measures (preventive and protection measures and flow management policies), legislation (mandatory permits and regulations), infrastructure, facilities and equipment, staff (number and qualifications), funding, and motivation for heritage conservation.

To adequately manage the proposed numerical estimates in accordance to both the conservation management objectives and visitor quality experience, some preventive and protection measures have been suggested, such as establishing public access restrictions during periods of nesting birds, the physical protection of the Roman remains by fences in order to avoid thefts and plundering, and 
controlling access to the inaccessible rooms of the Fort in order to guarantee the safety of the visitors.

An ethical code in which the attitudes and expected behaviours of the public are suggested should be drafted. Furthermore, it is necessary to implement a Public Use Plan, regulating visitor use in the Nature Reserve and Fort, and a heritage interpretation program (including a signage system) is a highly recommended tool to facilitate the intellectual and emotional visitor connection in order to enhance the enjoyment and quality of the visitor experience.

The necessary staff for the site includes two wardens ( 1 by day and 1 by night) with supervision and custody functions, as well as one well-trained guideinterpreter with information, guidance and interpretation functions.

\section{Concluding remarks}

The programme of research described in this paper was designed to support the application of the concept of carrying capacity to the Island of Chikly and the Fort of Santiago. This study is carried out as a preventive tool before the development of recreational activities. The results have defined the most appropriate activities for the best visitor experience, without impacting the natural and cultural resources. Additionally, management guidelines and recommendations have been provided, derived from the analysis of site conditions and the resource conservation assessment.

A combined methodological approach including management objectives, conservation standards and related indicators, and a numerical visitor estimate has been applied in this RCC assessment for the Nature Reserve of Chikly and also for the Fort of Santiago.

An important scientific contribution of this research is the identification of conservation standards and related indicators for historical buildings. The natural resource approach has properly worked with cultural tangible resources but more research is needed because is an innovative and developing field.

This study's findings suggest a range of conservation standards, related indicators and associated carrying capacities for the Island of Chikly and the Fort of Santiago. The results indicate that the Fort is the most robust site, whilst the Island is a very fragile space. The consideration of both resources (the nature reserve and the historical building) as a whole reduced the carrying capacity not only for the island but also for the Fort, as the island ecological and spatial standards command the limiting factors.

The numerical estimate suggests 20 people-at-one-time (PAOT), divided into two groups of 10 visitors, because on the Island, the maximum number of groups encountered per day is 0 due to its small size and its significant avifauna. A total of 10 visitors for the Fort is below its PAOT. Thus, it is not at risk if people adopt ethical behaviours when visiting the site.

This project was implemented in collaboration with representatives of several institutions and NGOs and with Med-INA. The MAVA Foundation (MAVA3 "Culture and wetlands in the Mediterranean: Using cultural values for wetland restoration") has financially supported this research project. 


\section{References}

[1] Graefe, A., Vaske, J. and Kuss, F., Social carrying capacity: An integration and synthesis of twenty years of research, Leisure Sciences, 6, pp. 395-431, 1984.

[2] Stankey, G. and Manning R., Carrying capacity of recreation settings. $A$ Literature Review: The President's Commission on Americans outdoors. US Gov. Printing Office, Washington, pp. M47-M57, 1986.

[3] Kuss, F., Graefe, A. and Vaske J., Visitor Impact Management: A Review of Research, National Parks and Conservation Association, 256pp., 1990.

[4] O'Reilly, A. M., Tourism carrying capacity. In Medlik (ed.): Managing Tourism. Butterworth-Heinemann, Oxford. pp. 301-306, 1991.

[5] Butler, R.W., The concept of Carrying Capacity for Tourism Destinations: dead or merely buried? Progress in Tourism and Hospitality Research, 2, pp. 283-293, 1996.

[6] Liddle, M., Recreation Ecology. The ecological impact of outdoor recreation and ecotourism. Chapman and Hall. 1997.

[7] Hammit, W.E. and Cole, D.N., Wildland recreation: ecology and management, New York: John Wiley and Sons, 361pp., 1998.

[8] Manning, R., Visitor experience and resource protection: A framework for managing the carrying capacity of National Parks. Journal of Park and Recreation Administration, 19(1), pp. 93-108, 2001.

[9] Manning, R., Wang B., Valliere W., Lawson S. and Newman P., Research to Estimate and Manage Carrying Capacity of a Tourist Attraction: A study of Alcatraz Island. Journal of Sustainable Tourism, 10(5), pp. 388-404, 2002.

[10] Pedersen, A., Managing Tourism at World Heritage Sites: a Practical Manual for World Heritage Sites Managers. UNESCO, Paris, 2002.

[11] Wagar, J. Alan. The carrying capacity of wildlands for recreation. Forest Sci. Monog. 7, Washington, DC: Society of American Foresters, 24pp., 1964.

[12] Shelby, B. and Heberlein, Th.A., Carrying capacity in recreation settings, Oregon State University Press, 164pp., 1986.

[13] Tarrant, M.A. and English, D.B.K., A Crowding-Based Model of Social Carrying Capacity: Applications for Whitewater Boating Use. Journal of Leisure Research, 28(3), pp. 155-168, 1996.

[14] Lindberg, K. and McCool, S.F., A critique of environmental carrying capacity as a mean of managing the effects of tourism development. Environmental Conservation, 25(4), pp. 291-2, 1998.

[15] Viñals, M.J., Morant, M., El Ayadi, M., Teruel, L., Herrera, S., Flores, S. and Iroldi, O., A Methodology for determining the recreational carrying capacity of wetlands. In: Garrod and Wilson. Marine Ecotourism. Issues and experiences. Channel View Pub, England, pp. 79-99, 2003.

[16] Troitiño, M.A., Estudio previo para la revisión del Plan Especial de la Alhambra y Alijares. Patronato de la Alhambra y el Generalife, 1999. 
[17] Magablush, K. and Al-Shorman, A., The physical carrying capacity at the cultural heritage site of Petra. Tourism Analysis, 13, pp. 511-515, 2008.

[18] Halasa, Z. and Viñals, M.J., Análisis de la afluencia de visitantes en el sitio Patrimonio de la Humanidad de Petra (Jordania). Turismo y gestión de espacios protegidos. Tirant lo Blanc, pp. 637-648, 2010.

[19] Cho Seaon-Hee Charge touristique et espace: le cas de Versailles, Mémoire de Master Insitut de Géographie, Université de Paris I, 1994.

[20] Manning, R., Wang B., Valliere W., Lawson S., Newman P., Research to Estimate and Manage Carrying Capacity of a Tourist Attraction: A study of Alcatraz Island. Journal of Sustainable Tourism, 10(5), pp. 388-404, 2002.

[21] Cole, D. and Carlson, Th., Numerical visitor capacity. A guide to its use in wilderness. Gen. Tech. Rep. RMRS-GTR-247. Fort Collins, 20pp., 2010.

[22] Lime, D., Research for determining use capacities of the Boundary Waters Canal Area. Naturalist 21(14), pp. 9-13, 1970.

[23] Frissell. S., Stankey, G., Wilderness environmental quality: Search for social and ecological harmony. Proceeding of the society of American Foresters annual conference. Soc. American Foresters, pp. 170-183, 1972.

[24] Stankey, G.H, Cole, D. N., Lucas, R.C, Petersen, M.E, and Frissell, S.S. The limits of acceptable change (LAC) system for wilderness planning. Gen. Tech. Rep. INT-176. Ogden, UT: USDA Forest Service, 37pp., 1985.

[25] Graefe, A.R., Kuss, F.R. and Vaske, J.J, Visitor impact management: the planning framework. Washington, National Parks and Conservation Association, 105pp., 1990.

[26] National Park Service, The visitor experience and resource Protection (VERP) Framework: A handbook for Planners and Managers. Publication No. NPS D-1215. USD National Park Service, Denver, CO, 103pp., 1997.

[27] Abdennadher, A. Contribution à l'étude de l'éco-biologies des oiseaux d'eau dans le lac Nord de Tunis: Hivernage, régime alimentaire et reproduction du goéland leucophée (Larus michahellis) sur l'ilot de Chikly. Mémoire de Master. Inst. National Agronomique de Tunisie, 84pp., 2005.

[28] Abdennadher, A.; Ramirez, F.; Romdhane, M.S.; Ruiz, X.; Jover, LL. and Sanpera, C., Biomonitoring of coastal areas in Tunisia: Stable isotope and trace elements analysis in the Yellow legged Gull. Marine Pollution Bulletin, 60, pp. 440-447, 2010.

[29] Narkhede, P.G. and Morris, I., Conservation of Forts in Maharashtra through appropriate tourism development policy. Architecture, time space and people, pp. 16-22, 2011.

[30] García Grinda, J.L., Santiago de Chikly: una fortaleza española en Túnez. AECID, Madrid, 2003.

[31] Stankey, G.H. and McCool, S.F., Carrying Capacity in recreational settings: Evolution, appraisal and application. Leisure Sciences, 6(4), pp. 453-473, 1984.

[32] Manning, R., Budruk. M., Valliere, W., Lawson, S. and Laven, D., Research to Support Carrying Capacity Analysis at Boston Harbor Islands National Recreation Area. University of Vermont Park Studies Laboratory, 2001. 
[33] Cifuentes, m., 1992. Determinación de la capacidad de carga turística en áreas protegidas. Ed. Turriable, Costa Rica, 34pp., 1992.

[34] Ceballos-Lascurain, H. Tourism, Ecotourism and Protected Areas. IUCN, 1996.

[35] Boullon, R., Planificación del espacio turístico. Ed. Trillas. México, 1985.

[36] Hall, T., The Hidden Dimension. Anchor Books, New York, 1966.

[37] World Tourism Organization. Indicators of sustainable development for tourism destinations. Guidebook. WTO, Madrid. 2005.

[38] Tran Nghi, Nguyen T.L., Nguyen D.T., Dang Mai, and Dinh X.T., 2007. Tourism carrying capacity assessment for Phong Nha-Ke Bang and Dong Hoi, VNU Journal of Science, Earth Sciences, 23, pp. 80-87, 2007. 